\title{
On the chronology and use of timber in the palaces and palace-like structures of the Sasanian Empire in "Persis" (SW Iran)
}

\author{
Morteza Djamali a,*, Alireza Askari Chaverdi ${ }^{\mathrm{b}}$, Silvia Balatti ${ }^{\mathrm{c}}$, Frédéric Guibal ${ }^{\mathrm{a}}$, Coralie Santelli ${ }^{\mathrm{a}}$

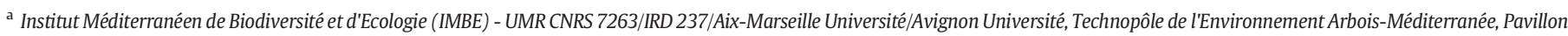 \\ Villemin, BP80, 13545 Aix-en-Provence, Cedex 04, France \\ ${ }^{\mathrm{b}}$ History Department, Shiraz University, Shiraz, Iran \\ c Institut für Klassische Altertumskunde, Christian-Albrechts-Universität zu Kiel, Leibnizstraße 8, 24118 Kiel, Germany
}

Keywords:

Tree cultivation

Cupressus sempervirens

Persian garden

Fars, Zagros

\begin{abstract}
A B S T R A C T
Timber in an archaeological context can be used to establish chronologies, to understand the history of architecture and to reconstruct cultural landscapes and natural vegetation in the past. In this study, we use the xylological identifications and radiocarbon dating results of five timber fragments recently discovered in three palaces or palace-like structures in Fars (SW Iran) dating back to the period of the Sasanian Empire (224-651 CE). We show that Qal'a-ye Dokhtar, a fortified palace to the north of Firuzabad, was constructed during the power transition from the Parthian to the Sasanian period. On the other hand, the so-called Palace of Ardashir I besides Firuzabad, was accomplished after the power takeover by the Sasanians and the political stabilisation of SW Iran under the reign of Ardashir I (224-240 CE) and his son Shapur I (240-270 CE). We also demonstrate that the 'Palace of Sarvistan' was mainly used right after the fall of the Sasanian Empire during the first centuries of Islamic domination over Iran. The discovery of timber in stone-dominated Sasanian architecture adds information on timber use in the Late Antique Near East. Mediterranean cypress (Cupressus sempervirens L.) was the only timber found in Sasanian palatial architecture, and its use suggests that the tree was one of the major cultivated elements in ancient 'Persis' most probably for its shade, beauty and building timber, but possibly also for its symbolic significance and sacred status to the Zoroastrians. Cypress trees may have played a major role in Persian gardens since antiquity, along with plane trees.
\end{abstract}

\section{Introduction}

The Sasanian Empire (224-651 CE) was the most powerful political and economic rival of the Roman Empire for about half a millennium. The Empire was established by Ardashir I (224-240 CE) in $224 \mathrm{CE}$, after he had defeated the last Parthian King Ardawan (Artabanus IV) in the plains of Hormozgan in Southern Iran (Frye, 1983; Wiesehöfer, 2001; Daryaee, 2013). Similar to the Teispids and the Achaemenids (550-330 BCE) centuries before, the Sasanians also rose to power and established their empire first in 'Persis', the modern province of Fars in Southwestern Iran (Alram and Gyselen, 2003; Weber, 2016). Already in the Early Sasanian period, Persis stood out due to a large-scale urbanisation project and extensive agricultural production, which was guaranteed by the development of sophisticated irrigation systems (Daryaee, 2003; Mousavi and Daryaee, 2012). Over time, many cities were built in the province, these hosted the immigrant populations

\footnotetext{
* Corresponding author.

E-mail address: morteza.djamali@imbe.fr (M. Djamali).
}

from the countryside and deported people (Wiesehöfer, 2001). The Sasanian 'Kings of Kings' also constructed a number of impressive palaces, fortifications, and Zoroastrian fire temples in Fars (Huff, 1986; Mousavi and Daryaee, 2012). Among the most famous of these buildings are the fortified complex of 'Qal'a-ye Dokhtar' and the 'Palace of Ardashir I' (or the so-called 'Ateshkadeh' or 'Ātaškada') near modern Firuzabad, both generally dated to Ardashir I's reign, and the 'Palace of Sarvistan' (hereafter 'Sarvestan'), near the modern town of Sarvestan, a building of uncertain function dated to the Late Sasanian-Early Islamic period (Fig. 1) (Bier 1986; Huff 2009; Askari Chaverdi 2011). Particular architectural features of these structures are the chahartaq (also chāhārtāq), a dome built on squinches above a square hall. These can be considered as the major Sasanian architectural innovation contributing into the later Middle Eastern architecture. Furthermore, the ayvan (also ayvān and $\bar{i} w \bar{a} n$ ) also developed in the area, this is a large vaulted hall walled on three sides and open at the front (Huff, 1986; Huff and O'Kane, 1990; Callieri, 2014). Sasanian architecture certainly influenced the Early Islamic palatial architecture and urban design in Southern Iran, in Iraq and to some extent also in Syria; however the nature and degree of this influence is still a matter of debate (Fontana, 1986; Huff, 1986; Bier, 1993). 


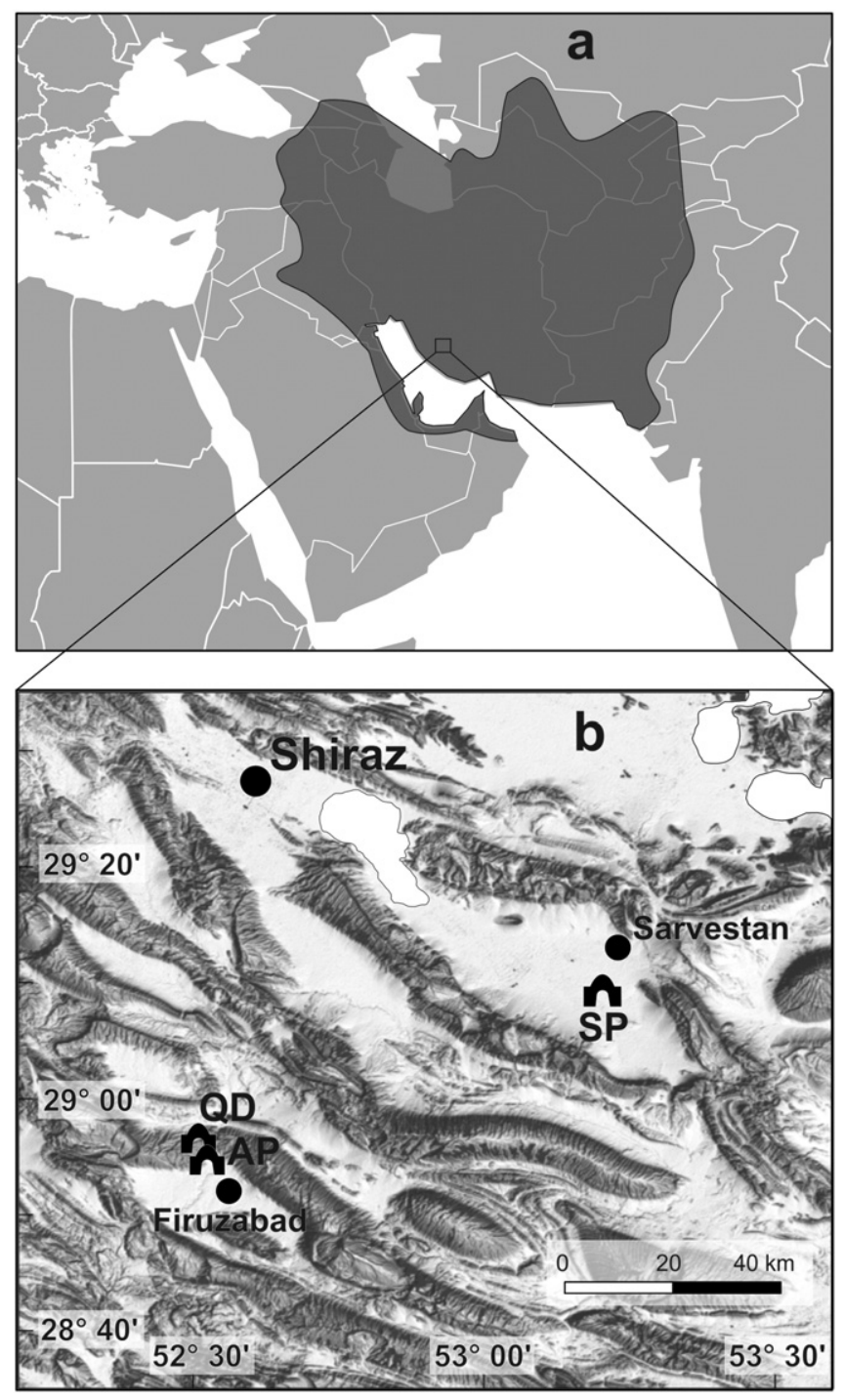

Fig. 1. a. The Sasanian Empire during the reign of Shapur I (240-270 CE). b. Position of the study sites: QD: Qal'a-ye Dokhtar, AP: Palace of Ardashir I, SP: Palace of Sarvestan.

Although a chronology has been suggested for Ardashir's palaces, which was mainly based on the coins discovered during the excavations at the sites (Huff, 1978), there has been, until now, no absolute dating available to confirm the suggested chronologies. The situation is even more complicated for the Palace of Sarvestan, for which a date encompassing the Sasanian and Early Islamic period has been attributed by archaeologists (Bier, 1986; Askari Chaverdi, 2009).

Another problem concerning the aforementioned three buildings and Sasanian architecture in general is that, to date, there have been no archaeobotanical data available on the use of timber in the palaces and other Sasanian structures. Fortunately, wood samples have recently been discovered in the excavated materials and wall structures of some Sasanian monuments of Fars (Askari Chaverdi, 2009). These samples are of great importance in order to understand not only the building techniques of Sasanian architecture but also the arboricultural history and the use of timber in ancient Persia. Timber fragments in archaeological excavations can provide a wealth of information on the chronology of archaeological sites, the history of architecture and technology, agricultural practices, and the past distribution of plant species in the landscape (e.g. Rival, 1991).
In this study, five timber fragments coming from the aforementioned Sasanian palaces and palace-like structures were analysed and radiocarbon-dated. Our main objectives were:

i. to present a material source useful to provide an absolute chronology of the buildings and consequently also to give information on the 'history' of the construction and use of the buildings;

ii. to provide information on the type of timber used in the construction of Sasanian buildings and;

iii. to use the datings and wood identifications to shed new light on the history of tree cultivation in ancient Iran.

\section{Material and methods}

Five wood samples were collected from three monuments: the Palace of Ardashir I to the north of Firuzabad ( $28^{\circ} 53^{\prime \prime} 51.44^{\prime \prime} \mathrm{N}, 52^{\circ} 32^{\prime \prime} 20.46^{\prime \prime} \mathrm{E}$, $1364 \mathrm{~m})$, Qal'a-ye Dokhtar on the road from Shiraz to Firuzabad ( $28^{\circ} 55^{\prime \prime}$ $14.79^{\prime \prime} \mathrm{N}, 52^{\circ} 31^{\prime \prime} 47.10^{\prime \prime} \mathrm{E}, 1490 \mathrm{~m}$ ), and the Palace of Sarvestan situated to the east of Lake Maharlu (also Maharlou) in the plain of Shiraz (29 $11^{\prime \prime} 44.20^{\prime \prime} \mathrm{N}, 53^{\circ} 13^{\prime \prime} 51.85^{\prime \prime} \mathrm{E}, 1547 \mathrm{~m}$ ). Fig. 2 displays the exact position of each wood fragment in the architectural plans of the buildings. Here are the descriptions of the studied wood fragments:

\begin{tabular}{cl}
\hline Dokht-1 & $\begin{array}{l}\text { Wood fragment cut from a timber in the western part of southern wall } \\
\text { of room } 16 \text { of Qal'a-ye Dokhtar (Fig. 2a). }\end{array}$ \\
\hline Ard-1 & $\begin{array}{l}\text { Wood fragment from the archaeological debris in the northwestern } \\
\text { corner of ayvan A of the Palace of Ardashir I (Fig. 2b). }\end{array}$ \\
Sarv-1 & $\begin{array}{l}\text { Timber section from the wall located in the southwestern corner of } \\
\text { room } 9 \text { of the Palace of Sarvestan (Fig. 2c; Fig. } 4 \mathrm{a} \text { ). }\end{array}$ \\
Sarv-2 & $\begin{array}{l}\text { Wood fragment from the debris in the northeastern corner of room } 1 \\
\text { supporting the large dome at the same place (Fig. 2c). }\end{array}$ \\
Sarv-3 & $\begin{array}{l}\text { Timber section from the wall in the northeastern corner of room } 10 \\
\text { supporting the small semi-dome at the same place (Fig. 2c; Fig. 4b). }\end{array}$
\end{tabular}

All five samples were AMS-radiocarbon dated in the Poznan Radiocarbon Laboratory (Table 1). For samples Sarv-1 and Sarv-3, which display almost complete series of tree-rings (Fig. 4a and b), only the outermost ring representing the date of the tree felling was subsampled for dating.

\section{Results and discussion}

\subsection{Chronology of construction and use of Sasanian royal palaces}

As reported in Table 1, the radiocarbon datings provide ages ranging from the 2nd to the 3rd century CE (Qal'a-ye Dokhtar and the Palace of Ardashir I) at the very beginning of the Sasanian Empire, and from the $7^{\text {th }}$ to the $9^{\text {th }}$ century CE corresponding to the centuries of domination of the Arab conquerors and the subsequent Iranian dynasties in the Islamic period (Fig. 3). These datings provide the first absolute ages from the Sasanian and early post-Sasanian palaces of Fars and help to shed some light on the history of the construction and use of the buildings in the Sasanian and post-Sasanian period.

\subsubsection{Qal'a-ye Dokhtar and the Palace of Ardashir I}

As illustrated in Fig. 3 (also reported in Table 1), the probability distribution curve of radiocarbon age for the Qal'a-ye Dokhtar sample points to a definitive absolute age older than 246 CE for this fortresspalace structure. This strongly suggests that it was constructed in the transitional period from the Parthian to the Sasanian rule over Persis. It seems that this absolute dating is in line with the historical events and the available archaeological remains. The Sasanian campaigns against the Parthians started in Persis at about 205-206 CE, when Pabag of the 'house' of Sasan, Ardashir I's father, dethroned the local ruler of the city of Istakhr (Weber, 2016). After succeeding his father, Ardashir I continued to conquer Parthian territories and finally defeated the last Parthian king on $28^{\text {th }}$ April 224 CE. In 226 CE, he was crowned in 


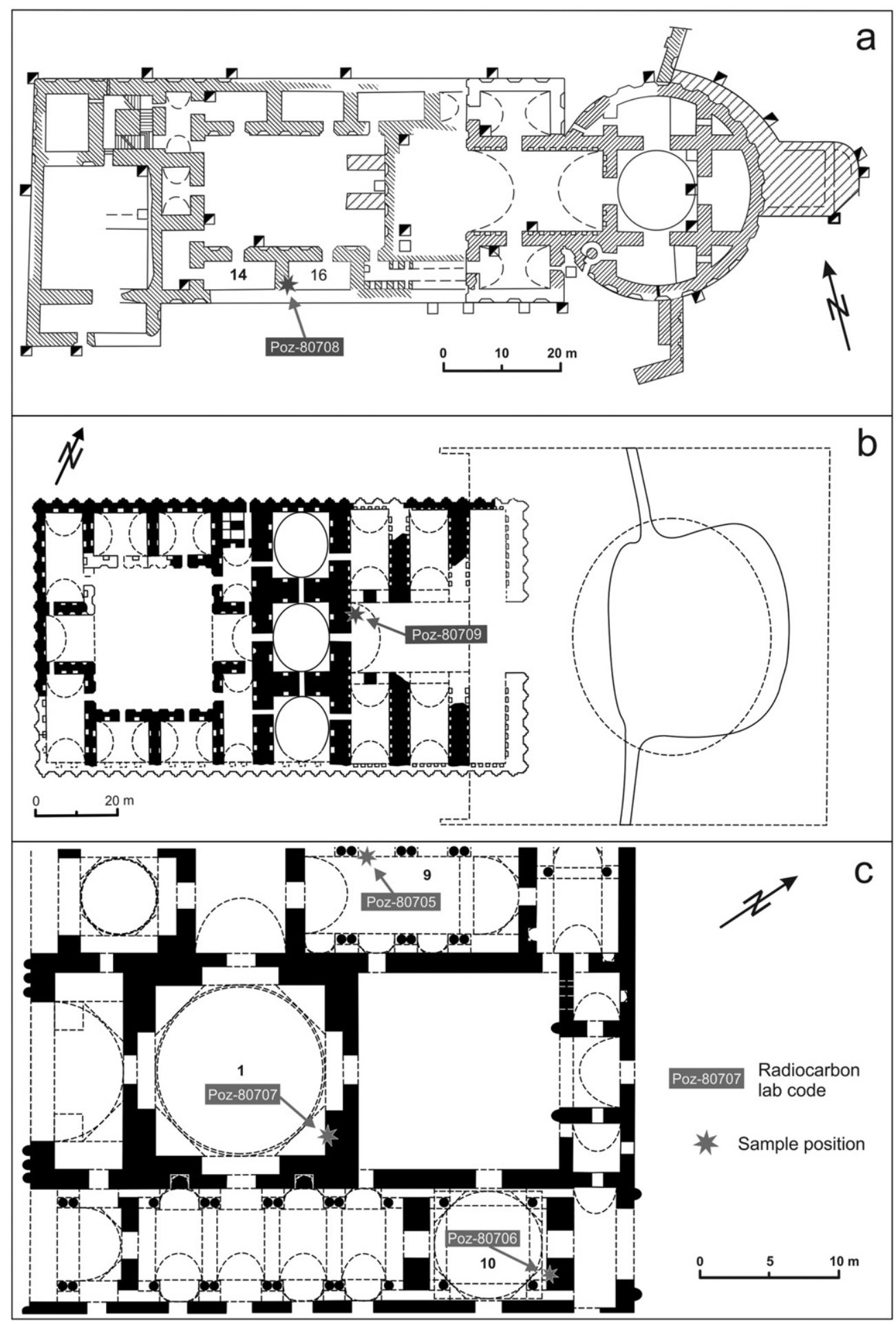

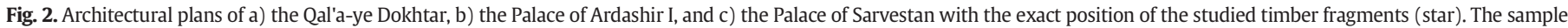

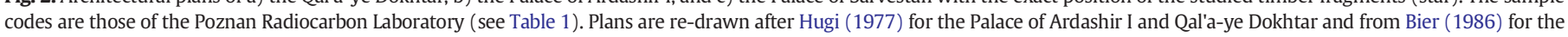
Palace of Sarvestan. See Materials and methods for more details.

Ctesiphon as "King of Kings", marking the beginning of Sasanian rule (Wiesehöfer, 2001; Daryaee, 2010). Qal"a-ye Dokhtar, a fortified palace that controls the access to the Firuzabad plain, was probably constructed in the Parthian-Sasanian transition period $\left(2^{\text {nd }}\right.$ to $3^{\text {rd }}$ century CE), most probably during King Ardashir I's reign, when he was fighting for supremacy in Persia (Huff, 2006). The fortress-palace would have been built with a defensive function before the final victory of Ardashir I over Artabanus IV in $224 \mathrm{CE}$; a fact that is also confirmed by pre-Sasanian coins found at the site (Huff, 1978). According to Huff
(1978), Qal'a-ye Dokhtar lost its importance after Ardashir's victory and the construction of the new palace (Palace of Ardashir I) in the plain of Firuzabad (Fig. 1). It only regained some military importance under King Yazdgerd III (632-651 CE) in his last efforts to organise resistance to the Arab conquest of Persia.

Absolute radiocarbon dating for the Palace of Ardashir I, near modern Firuzabad, suggests an age older than 257 CE (Fig. 3; Table 1), a time potentially corresponding to Shapur I's reign (240-270 CE). The comparison of the probability curves of samples from the two palaces 
Table 1

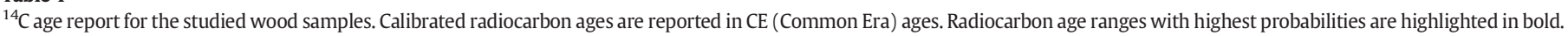
Calibrations were performed in Calib 7.1 (Stuiver et al., 1993) based on Intcal13 calibration dataset (Reimer et al., 2013).

\begin{tabular}{|c|c|c|c|c|c|c|}
\hline \multirow[b]{2}{*}{ Sample } & \multirow[b]{2}{*}{ Provenance } & \multirow[b]{2}{*}{ Context } & \multirow[b]{2}{*}{${ }^{14} \mathrm{C}$ lab code } & \multirow[b]{2}{*}{${ }^{14} \mathrm{C}$ age (yr BP) } & \multicolumn{2}{|c|}{ Calibrated ${ }^{14} \mathrm{C}$ age ranges (CE) } \\
\hline & & & & & $1 \sigma$ range & $2 \sigma$ range \\
\hline \multirow[t]{3}{*}{ Sarv1 } & Palace of Sarvestan & Room9 & Poz-80705 & $1315 \pm 30$ & 660-694 (0.72) & $655-724(0.74)$ \\
\hline & & & & & 704-706 (0.01) & $739-767(0.26)$ \\
\hline & & & & & $746-763(0.27)$ & \\
\hline \multirow[t]{2}{*}{ Sarv2 } & & Room10 & Poz-80706 & $1280 \pm 30$ & $682-720(0.59)$ & $664-773(1)$ \\
\hline & & & & & $741-767(0.41)$ & \\
\hline \multirow[t]{3}{*}{ Sarv3 } & & Room1 & Poz-80707 & $1220 \pm 30$ & $726-738(0.1)$ & $692-747(0.22)$ \\
\hline & & & & & $768-779(0.11)$ & $762-887(0.78)$ \\
\hline & & & & & $789-870(0.78)$ & \\
\hline \multirow[t]{2}{*}{ Dokht1 } & Qal'a-ye Dokhtar & & Poz-80708 & $1835 \pm 30$ & $134-216(1)$ & $86-110(0.05)$ \\
\hline & & & & & & $115-246(0.95)$ \\
\hline \multirow[t]{3}{*}{ Ard1 } & Palace of Ardashir I & & Poz-80709 & $1820 \pm 30$ & 139-197 (0.66) & $90-99(0.01)$ \\
\hline & & & & & $207-234(0.34)$ & $124-257(0.95)$ \\
\hline & & & & & & $296-320(0.04)$ \\
\hline
\end{tabular}

also suggests that the Palace of Ardashir I could also have been completed after Qal'a-ye Dokhtar, although, the radiocarbon dates provide no absolute certainty as to which of the two was built first (Fig. 3). These data are in accordance with the chronology suggested by historians and archaeologists (Huff, 1978). The strategic position and the fortifications of Qal'a-ye Dokhtar indicate the military use of this site and/or the necessity for protection of the royal family and the administrative centre of the young expanding kingdom of Ardashir I; while the absence of fortifications in the Palace of Ardashir in the Firuzabad plain shows that a degree of stability was already attained by the completion of the latter palace. Only after the Sasanian supremacy was definitively established, Ardashir I would have decided to build a residential palace in the well-watered plain of Firuzabad, a perfect starting place for his programme of revitalisation of land use and agriculture (Huff, 1978).

\subsubsection{Palace of Sarvestan}

All radiocarbon datings for wood samples of the Palace of Sarvestan gave post-Sasanian ages (Table 1 ; Fig. 3 ). The highest age probability for Sarv- 1 falls from the middle $7^{\text {th }}$ to the early $8^{\text {th }}$ centuries CE $(655-$ 724 CE). Sarv-2 sample gives the highest age probabilities for the middle $7^{\text {th }}$ to middle $8^{\text {th }}$ centuries CE (664-773 CE). Finally, sample Sarv-3 gives the highest probabilities for the middle $8^{\text {th }}$ to the end of the $9^{\text {th }}$ centuries CE (762-887 CE). The chronology of Sarvestan monuments has long been a matter of debate (Askari Chaverdi, 2009). An initial attribution of the palace to the Achaemenid period was soon rejected when in the late $19^{\text {th }}$ and early $20^{\text {th }}$ centuries several western travellers and archaeologists such as Flandin, Coste, Dieulafoy, De Morgan and Reuther attributed the ruins of Sarvestan to the Sasanian period. The Sasanian King Wahram V (420-438 CE) was traditionally identified as the builder

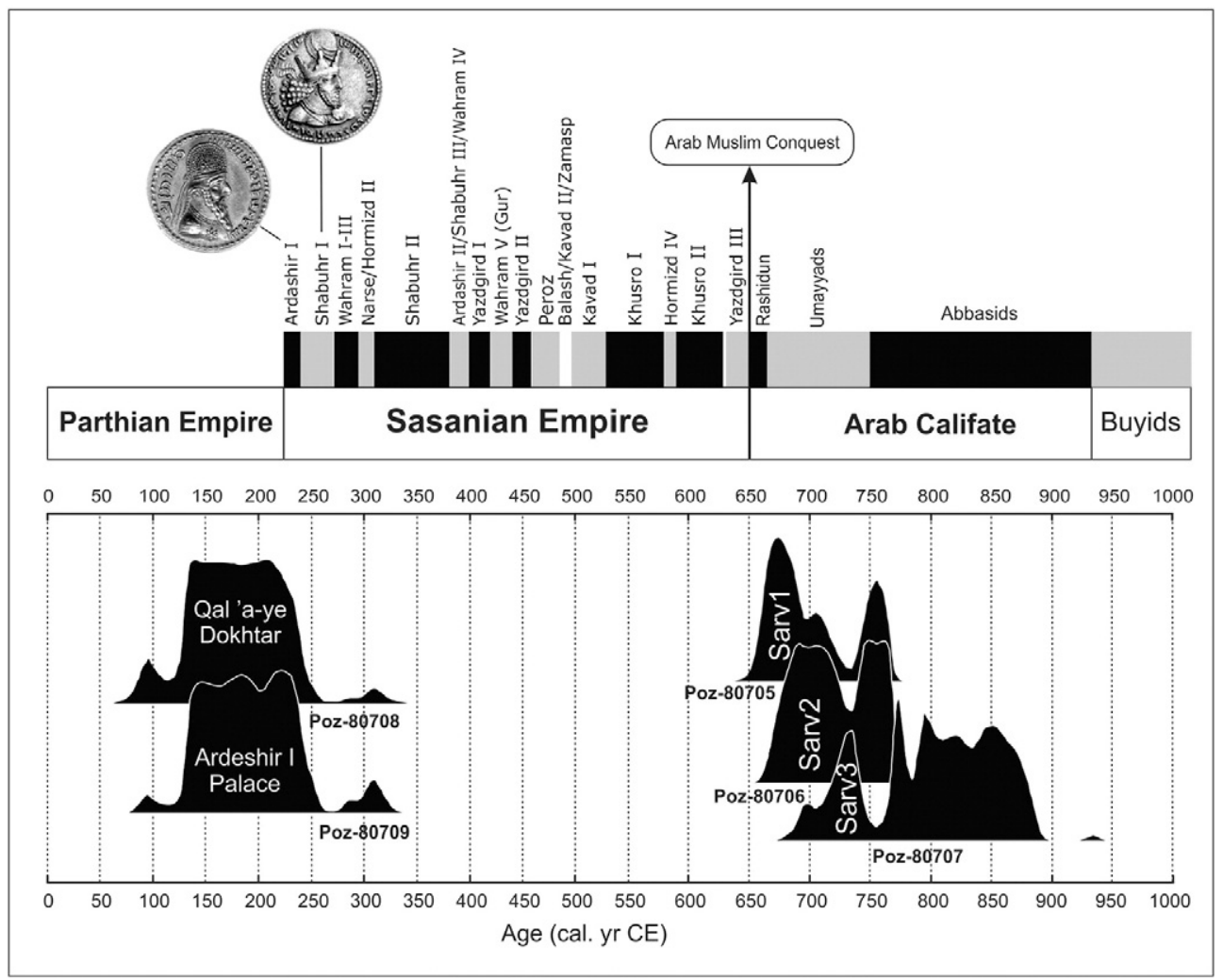

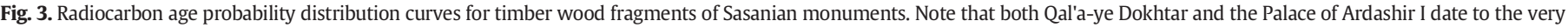

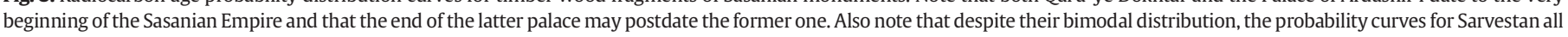
fall in the post-Sasanian and Early Islamic period. 
of the palace in the $5^{\text {th }}$ century CE. Later, a Sasanian date was also put into question by several archaeologists, after a more detailed examination of the architecture of the building complex (Bier, 1986). Especially the complex vault systems seem to have approached the structure of the Early Islamic architecture (see references in Huff, 1986). Some authors went even further by calling into question not only the date but also the function of the building complex. For instance, Bier (1986) suggested that the Palace of Sarvestan served as a fire temple during the first three centuries of the Islamic period. This is a very important observation from a historical perspective as it also suggests that the Arab conquerors arrived at a compromise with the Zoroastrian religious authorities and that Zoroastrianism would have been practiced for centuries after the establishment of the Islamic domination over Persia (Askari Chaverdi, 2009). Continuity in the settlement structures and their use has also been observed at several other sites in Iran in the transitional Sasanian-Islamic period (Morony, 2013). New archaeological excavations that aimed at attributing a robust chronology to the Sarvestan complex were conducted at the site by an Iranian team of archaeologists directed by Askari Chaverdi in 2002. The excavations revealed that the building complex was mainly used during the Early Islamic period with the most active occupation phase dating to the $10^{\text {th }}$ century $C E$.

Our dating results confirm the recent interpretations of the Sarvestan monuments by the aforementioned archaeologists (Bier, 1986; Askari Chaverdi, 2009, 2011). The Sarvestan complex must be dated to the transitional period from the Sasanian to the Islamic domination over Persis and clearly represents an example of Sasanian architectural heritage in post-Sasanian times. Bier's identification of the building complex as a Zoroastrian fire temple used for several centuries after the invasion of the Arab Muslims may thus stand, especially given that palatial architecture was closely linked to religious architecture in Sasanian Persia (Callieri, 2014).

\subsection{Archaeobotanical implications of cypress wood finds in Sasanian palaces}

All examined wood fragments belonged to Mediterranean cypress Cupressus cf. sempervirens. Fig. 4a and b illustrate two sections of Sarv-1 and Sarv-3 timbers coming from rooms 9 and 1, respectively (Fig. 2c). Fig. 4a-1 and 4b-1 illustrate the transversal and radial sections of the two timbers. Although the two timbers have almost the same diameter (11.0 and $8.5 \mathrm{~cm})$, their cutting ages are different. Sarv-3 was cut in a much younger age than Sarv-1, with 12 years against 36 years for Sarv1. Tree-ring series show different patterns, evidencing probable different growth conditions. Indeed, tree-rings of Sarv-1 timber show an initial period of low radial growth rate indicating adverse site conditions perhaps due to high competition (Fig. 4a). Sarv-3 timber shows the absence of latewood for its last ring suggesting the felling of the tree during the growing season. This tree has benefited from less stressed growth conditions as is seen in its wider earlywood rings (Fig. 4b).

The discovery of cypress wood fragments in the Sasanian and postSasanian palatial architecture provides new evidence not only on timber use in Sasanian and post-Sasanian architecture but also on the cultivation history of this tree in the inland plateaus of the ancient Near East. Contrary to walnut, olive tree, grapevine and plane tree, whose arboricultural history has been partly reconstructed in Persis using their pollen records (Djamali et al., 2011a; Djamali et al., 2015), the history of cypress cultivation cannot be easily reconstructed because of the difficulties in distinguishing its pollen from other members of the Cupressaceae family. Indeed, Cupressus pollen is grouped under Junipertype or Cupressaceae and cannot be easily distinguished from the pollen of Juniperus and Thuja (e.g. Beug, 2004). Juniperus is still surviving in some isolated populations in the central and southern Zagros (Browicz, 1982) but was more widespread in prehistory (Miller, 1982). Our archaeobotanical findings are thus of great importance to complete our picture of the arboricultural practices and wood use in the ancient Near East. Below, the implications of our finding of the cypress wood in the Sasanian archaeological sites are discussed in more detail.

\subsubsection{Ecology and distribution of C. sempervirens}

C. sempervirens is a Mediterranean conifer with very small and disjunct populations mostly constricted to the Eastern Mediterranean (Quézel, 1980). Outside the Mediterranean biogeographical region, in the continental Middle East, $C$. sempervirens is mainly present in a few localities in the valleys cutting the Alborz Mountains in Northern Iran (Riedl, 1968; Klein, 1994). In these valleys, C. sempervirens populations benefit from a mild Mediterranean Pluviseasonal Oceanic bioclimate restricted to a few N-S oriented valleys in natural geographic defiles (Djamali et al., 2011b). The climate of these restricted geographical zones is, however, in clear contrast to the rest of the vast Iranian and Eastern Anatolian plateaus which have a very continental climate with a long dry season (Djamali et al., 2011b, 2012). Browicz (1982) suggests that the isolated populations of $C$. sempervirens in southern Iran including a cypress population ( $>100$ trees) to the south of Shiraz might also be native to the region, thus forming relict populations. The presence of natural relict populations of Mediterranean elements in the southern Zagros Mountains has been known for a long time, as many isolated populations of Myrtus communis and some other Mediterranean trees can be found here and there (Migliore et al., 2012; Akhani and Deil, 2012). Although cypress is represented by only one species in Iran ( $C$. sempervirens), Iranian botanists distinguish three cypress varieties including i) pyramidal/fastigiate cypress: C. sempervirens var. pyramidalis (O.Targ.Tozz.) Nyman called 'sarv-e Shirazi' and 'sarv-e Kashi' in Persian, ii) cereiform cypress or C. sempervirens L. cv. cereiformis Rehd. called

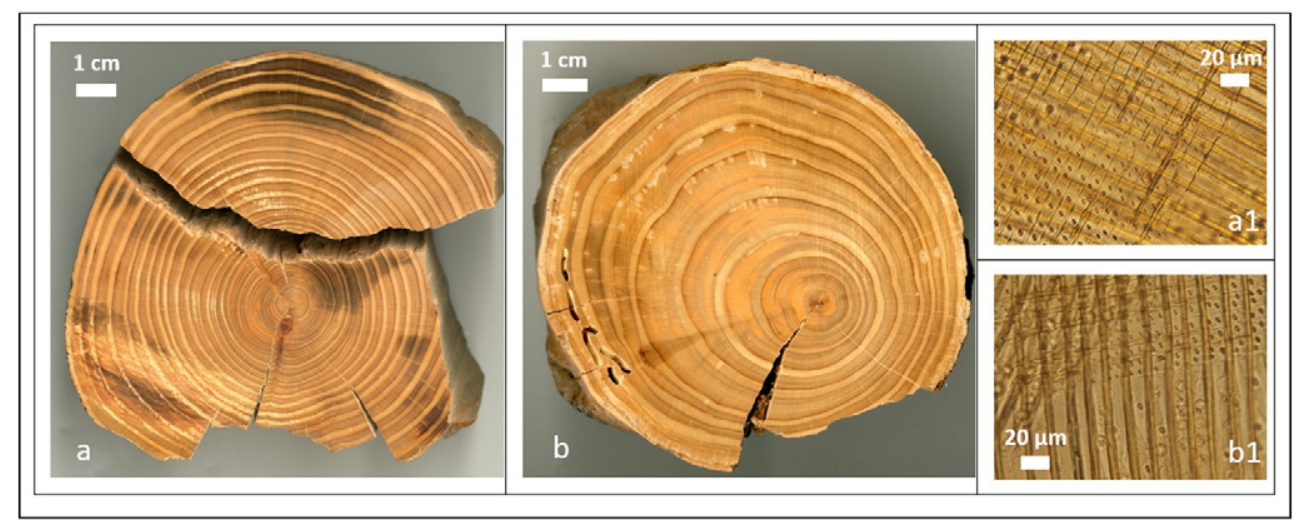

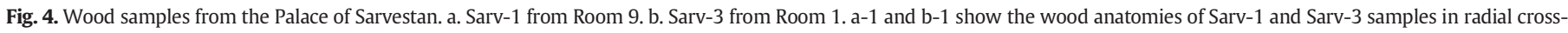

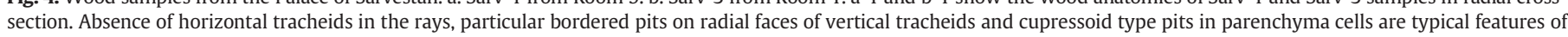
Cupressus. 
'sarv-e nāz' in Persian, and iii) horizontal cypress or C. sempervirens var. horizontalis (Mill.) Loudon called 'zarbin' in Persian (Alam, 1993). While the first two varieties are commonly planted as ornamental species in Iranian gardens, the third variety grows naturally in the Alborz Mountains. Today, all varieties and subspecies of $C$. sempervirens are, however, simply synonymous to Cupressus sempervirens L. according to The Plant List version 1.1. (http://www.theplantlist.org).

C. sempervirens, like many other Mediterranean elements, is sensitive to winter freezing temperatures and long dry seasons preventing its natural development under the Mediterranean xeric- and desertic continental bioclimates that dominate the Middle Eastern inlands (Djamali et al., 2011b). However, it is among the most resistant Mediterranean trees to winter temperature minima, whose leaves and cambium resist temperatures as low as -16 and $-29^{\circ} \mathrm{C}$, respectively (Quézel and Médail, 2003). This is why it can grow under irrigation in most parts of the continental Middle East. The relative indifference of C. sempervirens to the soil type also allows this tree to grow easily in different parts of Iran including the Fars region (e.g. Herbert, 1638; Alam, 1993).

\subsubsection{Cypress tree in the Iranian culture}

The cypress tree has often been associated with Iranian traditional beliefs. One of the pioneers of western studies on oriental religions, Lajard (1854), already linked the cypress tree to Zoroastrianism, the official religion of the Sasanian Empire, and quoted a great number of Persian and Arabic texts and short passages by Western orientalists that corroborated his statement. According to the tradition, the Prophet Zoroaster introduced the cypress cult in Persia by planting several cypress trees in the cities of ancient Khorasan in Northeastern Iran. In particular, the cypress planted by Zoroaster (or by his patron King Vishtaspa/Goshtasp) in front of the fire temple of the city of Kashmar in Khorasan (the so-called 'Cypress of Zoroaster') is of special significance for Zoroastrianism (Stausberg, 1998; Williams et al., 2016). The origin of this mythical tree is uncertain, but according to a Persian tradition Zoroaster received the cypress directly from heaven. King Vishtaspa, who was one of the earliest followers and supporters of Zoroaster, ordered all governors of his empire to come to the feet of the cypress tree to listen to Zoroaster, to adopt his message and to abandon the cult of the idols of Turan and China.

These legendary tales suggest that the cypress tree assumed an important symbolic and cosmic significance in the course of history of Zoroastrianism. The pyramidal form of cypress also reminds us of the flames which go from earth to heaven, thus perfectly symbolizing the Zoroastrian doctrine itself. Some scholars go even further and argue that the 'paisley' motif ('boteh' in Persian), the twisted teardrop-shaped motif frequently used on Persian and Central Asian textiles, might be a stylized form of a cypress tree bent under wind (Lajard, 1854). This interpretation might be confirmed by the presence of this motif on old silk tissues dating back to the Sasanian period (Eduljee, 2005). Most probably, cypress trees had a strong symbolic and cosmic meaning also in Sasanian Iran and at the Sasanian court, where the kings made large use of Zoroastrian symbolism in their political propaganda (e.g., in their coinage) (Schindel, 2013; Daryaee, 2013). Thus, it can be easily hypothesised that the Sasanian kings, who are known to have promoted agriculture and arboriculture (Pope, 1933; Wiesehöfer, 2001), particularly fostered the plantation of cypress trees in gardens and parks throughout their empire. The literary representation of this scenario is offered by a passage in the epic poem Shahnameh ("The Book of Kings'), in which Ferdowsi (ca.940-1020 CE) tells the story of the mythical Iranian king Fereydun who decorated the world with cypresses (and roses) in order to turn it into an earthly paradise (Khaleghi Motlagh, 1988). Cypress is frequently mentioned as a typical garden tree in later Persian poetry and continues to be an essential element of Persian gardens even today (Mahmoudi Farahani et al., 2016). It is very common to find centennial cypress trees in famous gardens in Iran such as the Fin Garden of Kashan, and shoots of the 'Cypress of
Zoroaster' are still worshipped in some places such as Cham and Abarkuh (Langer, 2008). Today, the tree is considered a symbol of immortality (Moynihan, 1980) because of its evergreen character that distinguishes it from many other deciduous trees planted in gardens.

Interestingly, the Middle and New Persian word for cypress is 'sarv' and the word 'Sarvestan' thus signifies the 'Garden of Cypress'. This suggests the presence of large-scale cypress plantations in the Sarvestan area at least since the foundation of the town of Sarvestan and probably also in earlier times.

\subsubsection{Cypress wood use in ancient architecture}

Cypress wood was used in a variety of ways in antiquity. In Mesopotamia, cypress (Akkadian: šurmenu) was considered a valuable wood, second only to cedar (i.e. Cedrus cf. libani). It was mainly imported as timber for palatial and temple architecture and shipbuilding since the $3^{\text {rd }}$ millennium BCE (Moorey, 1994). The royal inscriptions from Mesopotamia attest that cypress also started to be cultivated as ornamental tree in the gardens of the Neo-Assyrian and Neo-Babylonian palaces in the $1^{\text {st }}$ millennium BCE. Cypress wood continued, however, to serve as constructional material especially for roofing and tall doors. Timber of cypress was probably also used in Achaemenid palatial architecture. When describing the palace of Ecbatana (modern Hamadan), Polybius (2011) reports that all the woodwork was made of cedar and cypress (Polyb. 10.27). Therefore this species was probably already planted in the Persian gardens and parks by the Achaemenids. The conifer, represented as scene-divider on the reliefs of Persepolis, is traditionally believed to be cypress (Farrar, 2016), and the Greco-Roman authors also mention cypress among all sorts of trees planted in the Persian paradeisoi. Strabo (1930), for example, refers to the presence of cypress in the gardens and parks of Babylon in the Late Achaemenid period (Strab. 16.1.11), and Plutarch (1926) records a mixed forest of cypress and pine in a park in Northern Media (Plut. Artax. 25.1). The cypress trees of the Babylonian parks are said to have been cut by Alexander the Great to build part of his fleet (Strab. 16.1.11 Strabo, 1930).

Cypress wood was particularly appreciated in the Greco-Roman world for its durability, insect-repelling properties, and resistivity to humidity and seawater (Lieutaghi, 2004). These properties combined with the fragrant scent of the tree are among the most important characteristics of cypress wood as timber (The Wood Database available at: http://www.wood-database.com/mediterranen-cypress/).

Theophrastus (1916) praises cypress (Greek: kupárittos) for its durability and because it retains a fine and durable polish. He suggests that cypress wood was frequently used in house building and to construct the doors of the Greek temples (Theoph. Hist. pl. 5.7.4, 5.4.2 Theophrastus, 1916; cf. also Plin. HN 16.79 Pliny, 1945). The doors of the temple of Artemis at Ephesus, one of the Seven Wonders of the Ancient World, were made of cypress wood. Cypress trees often also adorned the surroundings of the temples of Artemis and of other gods in ancient Greece (Paus. 2.11.6, 2.13.3, 2.15.2, 3.22.9, 8.41.4, 10.38.9 Pausanias, 1918, 1926, 1935).

The Romans also used cypress (Latin: Cupressus) to construct buildings, statues and temple doors (Vitr. De arch. 2.18.12 Vitruvius, 1931; Plin. HN 16.79 Pliny, 1945; Liv. 27.37.11 Livy, 1943). Vitruvius stresses in particular, the importance of furring strips and ties made of durable cypress wood in the construction of vaults (Vitr. De arch. 7.3.1 Vitruvius, 1934). The insect-repelling character of cypress wood (Plin. HN 16.80-81 Pliny, 1945; Nardi Berti, 2006) greatly enhances the lifetime of its timber, and this fact surely increased its value as building material in the eyes of the Romans. In Roman Italy, cypress trees were probably not only cultivated in gardens, for their beauty and shade (Tac. Hist. 2.78 Tacitus, 1925), but also in timber plantations. Recent studies have shown that it was utilised in the construction of luxurious Roman villas, such as the Villa of Poppaea at Oplontis near Naples and the houses of Herculaneum (Moser et al., 2013; Moser et al., 2016). In Roman times, cypress wood was largely used in shipbuilding and other structures in long contact with water (Allevato et al., 
2009; Colaianni et al., 2011; Sadori et al., 2015). Cupressus wood is known for its resistance to fungal activity in humid environments (Okino et al., 2010) and its use in shipbuilding, well lining etc., indicates that this property was already recognised in ancient times. Several wrecks revealed the use of cypress wood in ancient naval architecture such as a plank and a wale in Fiumicino 1 (Boetto, 2008), the keel in the Bourse wreck in Marseilles (Rival, 1991), planks and wales in Pantano Longarini (Kampbell, 2007). Cypress wood was also the most used species for the construction of the medieval ship Dor 2001/1 (Liphschitz and Pulak, 2007).

\subsubsection{Cypress wood in the Sasanian palaces}

The use of cypress wood as building timber in the Sasanian palaces (and especially in vaulting) may have been recommended and/or practiced by the Roman engineers/workers, who were captured during the Parthian and Sasanian campaigns against the Roman Empire. We know from the ancient written sources that the Romans were well aware of the technological properties of cypress wood as timber and that in Roman architecture it was particularly appreciated in the construction of vaults (Vitr. De arch. 7.3.1). Moreover, the use of the technical skills and manpower of Roman prisoners of war can be seen in the construction of many bridges, dams and drainage/irrigation systems in Sasanian cities, which bear Roman architectural elements (Huff, 1986). Timber was most probably used in the Sasanian bridges in horizontal structures resting on the stony piers (Kleiss, 1992). However, considering the old tradition of cypress use in ancient Mesopotamia and its cultic value in ancient Iran - with possible extensive plantations in Persis and in other regions of the Empire - and also the indigenous status of $C$. sempervirens in Northern Iran and possibly also in Fars, it is highly probable that the Persians appreciated this wood as timber long before their first contacts with the Romans.

The most used building materials in Sasanian architecture are rubble with gypsum mortar and also mud bricks. Timber seems to have been a minor component of the Sasanian buildings, as it has not so far been reported from archaeological excavations of Sasanian structures. Our results show, however, that Sasanian architects did use some timber in their constructions. Although it is still not clear what was the exact function of timber in the Sasanian buildings, we know that in Islamic architecture, wood was used to support the vaulting systems during their construction and later for their reinforcement (Kleiss, 1992). Such utilisation may have been inspired by Sasanian architecture, where timber would have been used both for supporting vault systems and domes under construction and in later restoration works, especially in the remaking of facades. Sasanian palatial architecture took, in turn, inspiration from the Late Parthian brick masonry (Hauser, 2013; Callieri, 2014) and it may also have been influenced by earlier Near Eastern traditions, especially in the technology and use of locally available materials. The use of timber to reinforce mud brick and stone constructions, for roofing, doors and columns is attested to in the ancient Near East since the Neolithic period and characterises, in particular, the palatial and temple architecture of Mesopotamia and Elam in historical times (Moorey, 1994). In particular, the wood most commonly used in construction was coniferous wood for temples and palaces, while poplar was used for common buildings.

The choice of cypress wood as construction material in Sasanian palaces may have been determined by: i) the availability of the tree as a commonly planted species in parks, gardens, and along watercourses, ii) the absence or rarity of alternative suitable timbers, iii) the rectitude of its trunks, and iv) the well-known properties of the tree such as the resistance to insect attack, its high bending strength and moderate shrinkage values (Bektaș and Kurt, 2010; Dogu et al., 2011). The latter property is probably important in Sasanian architecture because, to avoid the formation and development of fissures and cracks in the gypsum mortar used in the vaults and domes, the wood should present the least variations in volume. It can also not be excluded that the exclusive choice of cypress wood for the construction of important buildings such as royal palaces and temples was favoured due to the symbolic and religious meaning of this tree for the ancient Iranians.

\section{Conclusions}

Wood preserved in the walls from mud brick- and stone-dominated Sasanian palaces and palace-like buildings of Fars have proven to be highly informative. On the one hand, it has shed more light on their history, on the other, it has also increased our knowledge of the use of wood in Sasanian architecture, as well as the history of arboriculture in ancient Persia. Our results suggest that:

1. the Qal'a-ye Dokhtar palace-fortification dates back to the period corresponding to Parthian-Sasanian power transition;

2. the Palace of Ardashir I near Firuzabad also dates back, at the very latest, to the very beginning of Sasanian rule;

3. the Palace of Sarvestan must be dated to the transitional period from the Sasanian to the Islamic domination over Iran (7th century CE) and was actively used during the Early Islamic period for a long time, which corresponds to several archaeological phases. It is a Sasanian heritage in the post-Sasanian period;

4. cypress was among the major cultivated trees in ancient Iran. Its plantation was most probably not only due to its shade and beauty but also to its timber;

5. the sacred status of cypress in Zoroastrianism may have been one of the reasons for its cultivation in gardens and possibly also in the vicinity of temples in ancient Persia.

Our initial results showed that wood fragments in the archaeological materials from palaces and other residential or religious monuments constitute an important source of information to understand the history of architecture and agricultural practices in the Antiquity. Future investigations of archaeological monuments dating to this period should thus include a systematic study of wood fragments in parallel with other archaeological techniques.

\section{Acknowledgment}

This study was funded by the Franco-German ANR-DFG project entitled "PALEO-PERSEPOLIS" (ANR-14-CE35-0026-01). We wish to thank the fruitful comments of Prof. Naomi F. Miller from the University of Pennsylvania and Prof. Josef Wiesehöfer from the University of Kiel. We are also grateful to Dr. Belinda Gambin (University of Malta) for her comments and the English-editing of the text.

\section{References}

Akhani, H., Deil, U., 2012. First observations on the flora and vegetation of three islands in the NW Persian Gulf (Iran). Phyton 52, 73-99.

Alam, H., 1993. Cypress. Encyclopedia Iranica 6, 505-508.

Alram, M., Gyselen, R., 2003. Sylloge Nummorum Sasanidarum Paris-Berlin-Wien. Band I, Ardashir I.-Shapur I. Austrian Academy of Science Press, Vienna.

Allevato, E., Russo Ermolli, E., Di Pasquale, G., 2009. Woodland exploitation and roman shipbuilding, first data from the Shipwreck Napoli C (Naples, Italy). Méditerranée 112, 33-42.

Askari Chaverdi, A., 2009. Archaeological excavations in the building known as the Palace of Sarvestan. Iranian J. Archaeol. Hist. 23, 36-65.

Askari Chaverdi, A., 2011. Archaeological excavation in the so-called "Palace of Sāsān" at Sarvestān. Fars. Sasanika Archaeol. 3:1-6. http://sasanika.org/esasanika/ archaeological-excavations-in-the-so-called-palace-of-sasan-at-sarvestan-fars/ accessed.

Bektaș, İ., Kurt, R., 2010. Principal mechanical properties of cypress wood (Cupressus sempervirens L.) naturally grown in Kahramanmaraș, Eastern Mediterranean of Turkey. G.U. J. Sci. 23, 357-362.

Beug, H.J., 2004. Leitfaden der Pollenbestimmung für Mitteleuropa und angrenzende Gebiete. Verlag Dr Friedrich Pfeil, München.

Bier, L., 1986. Sarvistan: a study in Early Iranian architecture. College Art Association Monographs, Monograph on the Fine Arts 41. Pennsylvania State University Press, University Park.

Bier, L., 1993. The Sassanian Palaces and their influence in Early Islam. Arts Orientalis 23, 57-66.

Boetto, G., 2008. L'épave de l'Antiquité tardive Fiumicino 1: analyse de la structure et étude fonctionnelle. Archaeonautica 15, 29-62. 
Browicz, K., 1982. Chorology of trees and shrubs in South-West Asia and adjacent regions. 1. Polish Academy of Sciences, Warszawa, pp. 1-172.

Callieri, P., 2014. Architecture et Représentations dans l'Iran Sassanide. Peeters, Leuven.

Colaianni, G., Scelza, F., Fiorentino, G., Pontrandolfo, A., Santoriello, A., Orrico, D., 2011 Well lining in ancient hydrological system of Fratte settlement (Salerno, Italy): cypress wood use in the Archaic period (6th-5th century BC). SAGVNTVM 11, 195-196.

Daryaee, T., 2003. The Persian Gulf Trade in Late Antiquity. J. World Hist. 14, 1-16.

Daryaee, T., 2010. Ardaxšîr and the Sasanian's rise to power. ANABASIS, Studia Classica et Orientalia 1, 236-255.

Daryaee, T., 2013. Sasanian Persia, the Rise and Fall of an Empire. I.B. Tauris \& Co Ltd., London.

Djamali, M., Miller, N.F., Ramezani, E., Akhani, H., Andrieu-Ponel, V., de Beaulieu, J.-L., Berberian, M., Guibal, F., Lahijani, H., Lak, R., Ponel, P., 2011a. Notes on the arboricultural and agricultural practices in ancient Iran based on new pollen evidence. Paléorient 36 (2), 175-188.

Djamali, M., Akhani, H., Khoshravesh, R., Andrieu-Ponel, V., Ponel, P., Brewer, S., 2011b. Application of the Global Bioclimatic Classification to Iran: implications for understanding the modern vegetation and biogeography. Ecologia Mediterranea 37, 91-114.

Djamali, M., Brewer, S., Breckle, S., Jackson, S.T., 2012. Climatic determinism in phytogeographic regionalization: a test from the Irano-Turanian region, SW and Central Asia. Flora 207, 237-249.

Djamali, M., Jones, M.D., Migliore, J., Balatti, S., Fader, M., Contreras, D., Gondet, S., Hosseini, Z., Lahijani, H., Naderi, A., Shumilovskikh, L., Tengberg, M., Weeks, L., 2015. Olive cultivation in the heart of the Persian Achaemenid Empire: new insights to agricultural practices and environmental changes reflected in a late Holocene pollen record from Lake Parishan, SW Iran. Veg. Hist. Archaeobotany 25, 255-269.

Dogu, D., Kose, C., Kartal, S.N., Erdin, N., 2011. Wood identification of wooden marine piles from the ancient Byzantine port of Eleutherius/Theodosius. Bioresources 6, 987-1018.

Eduljee, K.E., 2005. Boteh. Zoroastrian Heritage. http://www.heritageinstitute.com/ zoroastrianism/trade/paisley.htm/ (accessed 15/08/2016).

Farrar, L., 2016. Gardens and Gardeners of the Ancient World: History, Myth and Archaeology. Oxbow Books, Haverton.

Fontana, M.V., 1986. Art in Iran XII. Iranian pre-Islamic elements in Islamic art. Encyclopedia Iranica 11. http://www.iranicaonline.org/articles/art-in-iran-xii-iranian-preislamic-elements-in-islamic-art (accessed 15/08/2016).

Frye, R., 1983. The political History of Iran under the Sasanians: the rise of the Sasanian. In: Yarshater, E. (Ed.), The Cambridge History of the Iran 3. Cambridge University Press, Cambridge, pp. 116-180.

Hauser, S.R., 2013. The Arsacids (Parthians). In: Potts, D.T. (Ed.), The Oxford Handbook of Ancient Iran. Oxford University Press, Oxford, pp. 728-750.

Herbert, T., 1638. Some Years Travels Into Divers Parts of Asia and Afrique. R.Bi, London. Huff, D., 1978. Ausgrabungen auf Qal'a-ye Dukhtar bei Firuzabad 1976. AMI 11, 117-147.

Huff, D., 1986. Architecture: III: Sasanian period. Encyclopedia Iranica 2, 329-334.

Huff, D., O'Kane, B., 1990. Čahāțāq. Encyclopedia Iranica 4, 634-642.

Huff, D., 2006. Qal'a-ye Dokhtar. Encyclopedia Iranica 15. http://www.iranicaonline.org/ articles/qala-ye-doktar (accessed 15/08/2016).

Huff, D., 2009. Fürsten, Festungen und Feuertempel. Das sassanidische Imperium (224651 n. Chr.). In: Stronach, D., Mousavi, A. (Eds.), Irans Erbe in Flugbildern von GGerster. Philipp von Zabern Verlag, Mainz, pp. 76-109.

Hugi, H., 1977. Ghala-Dokhtar-Atechkade: monuments sasanides près de Firouzabad, Iran. Rapport préliminaire des projets de consolidation et restauration. Organisation Nationale pour la Conservation des Monuments Historiques.

Kampbell, S.M., 2007. The Pantano Longarini shipwreck: a reanalysis. PhD Thesis. Texas A\&M University.

Khaleghi Motlagh, D. (Ed.), 1988. Abu'l Oasem Ferdowsi: The Shahnameh (The Book of Kings) 1. University of New York Press, New York Persian Texts Series 1.

Klein, J.-C., 1994. La végétation altitudinale de l'Alborz Centrale (Iran). Institut Français de Recherche en Iran, Tehran.

Kleiss, W., 1992. Encyclopedia Iranica 6, 217-219.

Lajard, M.F., 1854. Recherches sur le culte du cyprès pyramidal chez les peuples civilisés de l'antiquité. Imprimerie Impérial, Paris.

Langer, R., 2008. Pīrān und Zeyāratgāh: Schreine und Wallfahrtsstätten der Zarathustrier im neuzeitlichen Iran. Acta Iranica 48. Leuven, Peeters.

Lieutaghi, P., 2004. Le livre des arbres, arbustes et arbrisseaux. Actes Sud, Arles Cedex.

Liphschitz, N., Pulak, C., 2007. Wood species used in ancient shipbuilding in Turkey: evidence from dendroarchaeological studies. Skyllis 8, 73-82.

Livy, 1943. History of Rome. VII: Books 26-27. Loeb Classical Library 367, Harvard University Press, Cambridge MA Translated by F. G. Moore.

Mahmoudi Farahani, L., Motamed, B., Jamei, E., 2016. Persian gardens: meanings, symbolism, and design. Landscape Online 46, 1-19.

Migliore, J., Baumel, A., Juin, M., Médail, F., 2012. From Mediterranean shores to centra Saharan mountains: key phylogeographical insights from the genus Myrtus. J. Biogeogr. 39, 942-956.

Miller, N.F., 1982. Economy and environment of Malyan, a third millennium B.C. urban center in Southern Iran. PhD dissertation. University of Michigan, USA
Moorey, P.R.S., 1994. Ancient Mesopotamian Materials and Industries: The Archaeological Evidence. Clarendon Press, Oxford.

Morony, M.G., 2013. The Islamic conquest of Sasanian Iran. In: Potts, D.T. (Ed.), The Oxford Handbook of Ancient Iran. Oxford University Press, Oxford, pp. 975-986.

Moser, D., Allevato, E., Clarke, J.R., Di Pasquale, G., Nelle, O., 2013. Archaeobotany at Oplontis: woody remains from the Roman Villa of Poppaea (Naples, Italy). Veg. Hist. Archaeobotany 22 (5), 397-408.

Moser, D., Nelle, O., Di Pasquale, G., 2016. Timber economy in the Roman Age: charcoal data from the key site of Herculaneum (Naples, Italy). Archaeol. Anthropol. Sci. http://dx.doi.org/10.1007/s12520-016-0406-0.

Mousavi, A., Daryaee, T., 2012. The Sasanian Empire: an archaeological survey, c.220-AD 640. In: Potts, D.T. (Ed.), A Companion to the Archaeology of the Ancient Near East. Wiley-Blackwell, Oxford, pp. 1076-1094.

Moynihan, E.B., 1980. Paradise as a Garden: In Persia and Mughal India. Scolar Press, London.

Nardi Berti, R., 2006. La struttura anatomica del legno ed il riconoscimento dei legnami italiani di piú corrente impiego. CNR-Ivalsa, Firenze.

Okino, E.Y.A., Santana, M.A.E., Alves, M.V.S., Melo, J.E., Coradin, V.T.R., Souza, M.R., Teixeira, D.E., Sousa, M.E., 2010. Technological characterization of Cupressus spp. wood. Floresta e Ambiente, Seropédica 17, 1-11.

Pausanias, 1918. Description of Greece. I: Books 1-2. Loeb Classical Library 93, Harvard University Press, Cambridge MA Translated by T. H. S. Jones.

Pausanias, 1926. Description of Greece. 2: Books 3-5. Loeb Classical Library 188, Harvard University Press, Cambridge MA Translated by T. H. S. Jones \& H. A. Ormerod.

Pausanias, 1935. Description of Greece. IV: book 8.22-10. Loeb Classical Library 297, Harvard University Press, Cambridge MA Translated by W. H. S. Jones.

Pliny, 1945. Natural History. Vol. 4: Books 12-16. Loeb Classical Library 370, Harvard University Press, Cambridge MA Translated by H. Rackham.

Plutarch, 1926. Lives. 11. Loeb Classical Library 103, Harvard University Press, Cambridge MA Aratus-Artaxerxes Galba-Otho. Translated by B. Perrin

Polybius, 2011. The Histories. IV: Books 9-15. Loeb Classical Library 159, Harvard University Press, Cambridge MA Translated by W. R. Paton.

Pope, A.U., 1933. A Sasanian garden palace. The Art Bulletin 15, 75-85.

Quézel, P., 1980. Biogéographie et écologie des conifères sur le pourtour méditerranéen. In: Pesson, P. (Ed.), Documents d'Ecologie Forestière. Gauthiers-Villars, Paris, pp. 201-255.

Quézel, P., Médail, F., 2003. Ecologie et biogéographie des forêts du bassin méditerranéen. Elsevier, Paris.

Reimer, P.J., Bard, E., Bayliss, A., Beck, J.W., Blackwell, P.G., Bronk Ramsey, C., Buck, C.E., Cheng, H., Edwards, R.L., Friedrich, M., Grootes, P.M., Guilderson, T.P., Haflidason, H. Hajdas, I., Hatté, C., Heaton, T.J., Hogg, A.G., Hughen, K.A., Kaiser, K.F., Kromer, B., Manning, S.W., Niu, M., Reimer, R.W., Richards, D.A., Scott, E.M., Southon, J.R., Turney, C.S.M., van der Plicht, J., 2013. IntCal13 and MARINE13 radiocarbon age calibration curves 0-50000 years cal BP. Radiocarbon 55, 1869-1887.

Riedl, H., 1968. Cupressaceae. In: Rechinger, K.H. (Ed.), Flora Iranica. 50, pp. 1-10.

Rival, M., 1991. La charpenterie navale romaine: matériaux, méthodes, moyens. Editions du CNRS, Paris.

Sadori, L., Allevato, E., Bellini, C., Bertacchi, A., Boetto, G., Di Pasquale, G., Giachi, G., Giardini, M., Masi, A., Pepe, C., Ermolli, E.R., Mariotti Lippi, M., 2015. Archaeobotany in Italian ancient Roman harbours. Rev. Palaeobot. Palynol. 218, 217-230.

Schindel, N., 2013. Sasanian coinage. In: Potts, D. (Ed.), The Oxford Handbook of Ancient Iran. Oxford University Press, Oxford, pp. 814-840

Stausberg, M., 1998. Faszination Zarathushtra. Zoroaster und die Europäische Religionsgeschichte der Frühen Neuzeit. De Gruyter, Berlin-New York.

Strabo, 1930. Geography. VII: Books 15-16. Loeb Classical Library 241, Harvard University Press, Cambridge MA Translated by H. L. Jones.

Stuiver, M., Reimer, P.J., Reimer, R., 1993. Extended ${ }^{14} \mathrm{C}$ database and revised CALIB radiocarbon calibration program. Radiocarbon $35,215-230$

Tacitus, 1925. Histories. I: Books 1-3. Loeb Classical Library 111, Harvard University Press, Cambridge MA Translated by C. H. Moore.

Theophrastus, 1916. Enquiry into Plants. 1: Books 1-5. Loeb Classical Library 70, Harvard University Press, Cambridge MA Translated by A. F. Hort.

Vitruvius, 1931. On Architecture. I: Books 1-5. Loeb Classical Library 251, Harvard University Press, Cambridge MA Translated by F. Granger.

Vitruvius, 1934. On Architecture. II: Books 6-10. Loeb Classical Library 280, Harvard University Press, Cambridge MA Translated by F. Granger.

Weber, U., 2016. Pāgab, der Vater Ardašīrs I., in der historiographischen Überlieferung. In: Binder, C., Börm, H., Luther, A. (Eds.), DiwanStudies in the History and Culture of the Ancient Near East and the Eastern Mediterranean, Festschfift für Josef Wiesehöfer zum 65. Geburtstag. Wellem Verlag, Duisburg, pp. 517-554.

Wiesehöfer, J., 2001. Ancient Persia: From 550 BC to 650 AD. I.B. Tauris, London.

Williams, A., Stewart, S., Hintze, A., 2016. The Zoroastrian Flame. Exploring Religion, History and Tradition. I. B. Tauris, London eds. 